\title{
Effect of microbial consortia on soil enzymatic activities of sorghum [Sorghum bicolor (L.) Moench] rhizosphere under glass house conditions
}

Y. Kavya*1, N. Trimurtulu ${ }^{2}$ and A. Vijaya Gopal ${ }^{1}$

${ }^{1}$ Department of Agriculture Microbiology, APGC, Acharya N.G. Ranga Agricultural University, Lam, Guntur (A.P.) India

${ }^{2}$ Acharya N.G. Ranga Agricultural University, Lam, Guntur (A.P.) India

\section{ARITCLE INFO}

Received : 12.02 .2020

Revised : 11.03 .2020

Accepted : 24.03.2020

KEY WORDS :

Microbial consortium, Dehydrogenase,

Phosphatase, Urease, Enzyme activity

*Corresponding author:

Email : kavyayerasi160@gmail.com

\begin{abstract}
A pot experiment was conducted under green house conditions to study the influence of microbial consortia on rhizospheric soil enzymatic activities at different intervals of sorghum growth. Microbial consortia along with different doses of chemical fertilizers and FYM were added to sorghum (CSV-27). Different soil enzymes viz., acid phosphatase, alkaline phosphatase, dehydrogenase enzyme and urease enzyme activity were monitored at zero DAS, 45 DAS, 90DAS and 120DAS in potculture. Treatment $\mathrm{T}_{10}$ (75\% RDF + Microbial consortium-2 +FYM) showed significantly highest enzymatic activity of all the enzymes at all intervals of crop growth compared to other treatments. While, except urease all the other three soil enzymes like dehydrogenase, acid phosphatase and alkaline phosphatase activities were significantly lowest in $\mathrm{T}_{11}(100 \%$ RDF). Microbial consortium-2 showed maximum enzymatic activity compared to microbial consortium-1.

How to view point the article : Kavya, Y., Trimurtulu, N. and Vijaya Gopal, A. (2020). Effect of microbial consortia on soil enzymatic activities of sorghum [Sorghum bicolor (L.) Moench] rhizosphere under glass house conditions. Internat. J. Plant Protec., 13(1) : 93-97, DOI : 10.15740/ HAS/IJPP/13.1/93-97, Copyright@ 2020: Hind Agri-Horticultural Society.
\end{abstract}

